\title{
Wacana Perbedaan Gender Dalam Artikel Pendidikan Seks Remaja (Analisis Wacana Kritis Artikel Seksualitas Majalah Hai Edisi 1995-2004)
}

\author{
Muria Endah Sokowati \\ Departemen Ilmu Komunikasi Universitas Muhammadiyah Yogyakarta \\ muriaendah@umy.ac.id
}

\begin{abstract}
Adolescence is a social category considered as apolitical, hedonist, consumptive, and uncritical. They often become the object of socialization and education of morality from adult. Many social institutions, including the media have subjugated their desire in the name of sex education. Hai magazine-segmented its product for teenage boys-displayed sexual contents for sex education in its articles. In those articles, Hai magazine has presented information relating to dominant sexual norms. This paper focuses on how Hai magazine has built discourse of gender differences in its articles. Using critical discourse analysis, the researcher revealed the attempt of Hai magazine to construct the ideal relationship of teenage boys and girls. The construction cannot be separated from the politics of Hai magazine to accommodate the parents' interest following sexual normative and conservative discourse. At the same time, Hai also supports sexual liberalism discourse, which becomes the part of media interest as cultural industry. As a result, Hai magazine has performed ambivalence idea of gender differences. The ambivalence is indicated from the idea of sexual attraction, the division of sexual roles, and emphatic strategy.
\end{abstract}

Keywords: adolescence, discourse, gender, sexuality

\begin{abstract}
Abstrak
Remaja adalah kategori sosial yang bersifat apolitis, hedonis, konsumtif dan tidak kritis. Untuk itu remaja kerap menjadi objek sosialisasi dan edukasi soal moralitas oleh orang dewasa. Penundukan hasrat remaja atas nama pendidikan seks banyak dilakukan oleh berbagai institusi sosial, termasuk media. Majalah Hai sebagai majalah yang ditujukan untuk remaja laki-laki menampilkan konten-konten seks dengan tujuan edukasi seks di dalam artikel-artikelnya. Dalam artikel tersebut, majalah Hai menyajikan informasi yang berkaitan dengan norma seks yang dipahami oleh mayoritas masyarakat. Tulisan ini secara khusus memfokuskan pada bagaimana Hai membangun wacana tentang perbedaan gender yang terdapat dalam artikel-artikel seksualitas yang bertemakan relasi laki-laki dan perempuan. Lewat metode analisis wacana kritis, peneliti menyingkap adanya upaya majalah Hai untuk mengkontruksi relasi laki-laki dan perempuan yang dianggap ideal. Konstruksi tersebut tidak dilepaskan dari politik majalah Hai untuk mengakomodasi kepentingan orang tua yang menganut paham seksualitas yang normatif dan konservatif sekaligus mendukung paham liberalisme seksual yang menjadi bagian dari kepentingan media sebagai industri budaya. Akibatnya majalah Hai menampilkan gagasan perbedaan gender yang ambivalen. Ambivalensi tersebut terlihat dalam gagasan majalah Hai tentang daya tarik seksual, pembagian peran secara seksual dan strategi empati.
\end{abstract}

Kata Kunci: gender, remaja, seksualitas, wacana 


\section{Pendahuluan}

\section{Artikel Seksualitas Majalah $\mathrm{Hai}$}

Majalah Hai adalah satu-satunya majalah remaja laki-laki yang pernah ada di Indonesia. Majalah remaja laki-laki tercantum dalam tagline "cermin kehidupan remaja pria" yang menegaskan majalah Hai menjadi refleksi apa dan bagaimana menjadi remaja laki-laki. Hai menjadi referensi remaja laki-laki dalam membentuk identitasnya.

Majalah Hai memasukkan konten lokal dan global sebagai implementasi strategi pemasaran Hai dalam menjangkau pasar remaja urban. Muatan-muatan lokal dan global identik dengan karakter remaja. Nilan (2006) menyatakan bahwa remaja negara dunia ketiga diasosiasikan dengan nilai-nilai lokal dan global. Kultur remaja merupakan kultur hibrid antara keduanya, sebagai bentuk negosiasi antara identitas personal dan kelompok, dan derasnya transformasi nilai-nilai dari barat yang kerap menjadi rujukan. Upaya Hai menyeimbangkan identitas global dan lokal disebut Baulch (2002) sebagai "A Trans-national Free-For-All”. Hai tidak selalu berkiblat pada barat, namun memposisikan konten lokal sejajar dengan konten global atau barat. Konten lokal dan global menghablur dan membentuk apa yang disebut Nilan sebagai kultur hibrid.

Dengan demikian, Hai memposisikan dirinya sebagai rujukan gaya hidup remaja laki-laki. Sebagai penegasan atas posisinya tersebut, Hai menempatkan dirinya sebagai "kakak" bagi para remaja pembacanya. Posisi sebagai kakak merupakan jalan bagi Hai untuk memberikan "nasehat" seputar gaya hidup remaja tanpa terkesan menggurui. Posisi sebagai kakak menunjukkan Hai sebagai pihak dominan dan lebih tahu dibandingkan remaja pembaca yang berada pada posisi inferior, sehingga harus diasuh dan dididik.

Sebagai rujukan gaya hidup remaja, Hai menyajikan konten yang khas dengan dunia remaja. Selain memberikan rujukan tentang fashion, musik, film, olahraga, dan hobi, Hai juga melengkapi dirinya dengan materi seksualitas. Materi seksualitas selalu menarik bagi siapa saja, terutama remaja. Konten seksualitas menjadi tema kontroversial karena dianggap mengancam moralitas sehingga tabu untuk dibahas. Akibatnya, tema-tema seks justru membangkitkan rasa ingin tahu yang besar di kalangan remaja. Sebagai institusi media yang komersial, Hai tentu saja tidak melepaskan peluang tersebut.

Seks didiskusikan pada remaja lewat pendidikan seks yang dianggap penting karena usia remaja menurut penjelasan biologis merupakan masa dimana organ-organ seksualnya mulai berkembang. Akibatnya remaja sudah memiliki hasrat seksual. Padahal dalam seksualitas prokreatif, hubungan seksual hanya dapat dilakukan oleh laki-laki dan perempuan yang terikat perkawinan. Berlakunya UU No. 1/1975 tentang Perkawinan yang menentukan batas usia menikah, bagi laki-laki 19 tahun dan perempuan 16 tahun menyebabkan remaja belum bisa menikah dan merealisasikan hasrat seksualnya.

Selain itu, lahirnya kelas menengah ikut mendorong remaja menunda perkawinan. Orang tua kelas menengah menghendaki anak-anak mereka melanjutkan ke pendidikan tinggi. Hal tersebut menyebabkan gap antara hasrat dan realisasi seksual bagi remaja. Di satu sisi organ reproduksinya sudah 
berfungsi, namun menurut norma sosial dan agama hubungan seks tidak boleh dilakukan di luar perkawinan. Remaja harus menunda perkawinan. Pada masa tunggu inilah remaja rawan melakukan tindakan-tindakan yang dianggap melanggar norma sosial dan agama, yaitu melakukan seks bebas.

Remaja dikonstruksi sebagai kelompok yang apolitis, hedonis dan tidak berpikir kritis. Hal ini menjadikan remaja objek sosialisasi dan edukasi soal moralitas oleh orang dewasa. Giroux (1998) menyatakan remaja diisi oleh hasrat fantasi dan kepentingan dari dunia orang dewasa. Remaja perlu ditundukkan hasrat dan perilakunya lewat wacana-wacana yang dibuat oleh orang dewasa, termasuk seksualitas. Usia remaja sebagai usia reproduktif secara seksual, dilekati harapan-harapan, seperti generasi penerus bangsa, agen pembangunan dan sebagainya, dituntut menahan hasrat seksualnya. Seks bebas, kehamilan, aborsi, pornografi merupakan ancaman karena dapat merusak harapan-harapan orang dewasa atas remaja. Untuk itulah pendidikan seks menjadi sarana pengontrol seksualitas remaja. Lewat pendidikan seks, Hai membangun wacana seksualitas remaja yang menjelaskan perilaku seksual yang normal, sehat, ideal dan diinginkan.

Lewat pendidikan seks, Hai menyampaikan konten seksualitas pada pembacanya. Artikel seksualitas menjadi sarana Hai untuk memberikan materi seksualitas secara edukatif sekaligus menghibur bagi pembacanya. Posisi sebagai kakak menjadi peluang Hai untuk menanamkan wacana-wacana seksualitas kepada pembacanya.

Konten seksualitas dimulai tahun 1990an, dilatarbelakangi banyaknya pertanyaan tentang seksualitas dari pembaca lewat telepon. Pembaca memiliki rasa ingin tahu yang besar tentang seksualitas, namun terhambat secara psikologis dalam mendiskusikannya dengan orang tua atau guru. Melihat potensi seks sebagai daya tarik bagi remaja, maka di tahun 1999 Hai membuat rubrik yang membahas problem tersebut dan berfungsi sebagai pendidikan seks remaja yang dikemas secara informatif dan edukatif. berikut:

Data artikel dan rubrik seksualitas tahun 1995-2004 adalah sebagai

Diagram 1. Artikel Majalah Hai Edisi Tahun 1995-2004

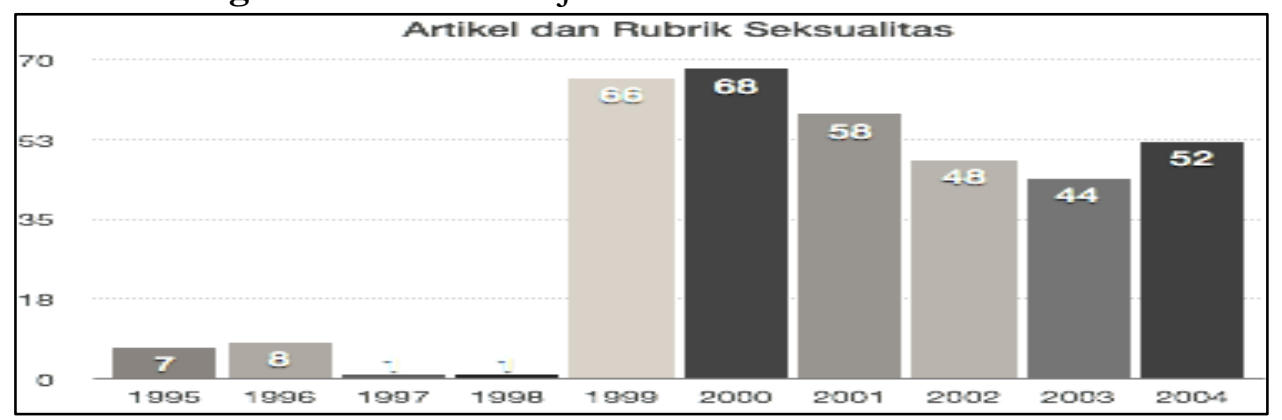

Sumber: Diolah dari Majalah Hai yang terbit pada tahun 1995-2004

Berdasarkan grafik tersebut, jumlah artikel seksualitas mengalami lonjakan drastis di tahun 1999. Sebenarnya sebelum tahun 1998 konten seks sudah marak dalam media massa, terutama film dan novel. Namun demikian tema ini masih kontroversial. Untuk itu, majalah Hai masih belum "berani”" menampilkan 
konten seks. Melonjaknya konten seksualitas terjadi bersamaan dengan dimulainya liberalisasi dan industrialisasi media yang membawa euforia kebebasan pers dan komodifikasi seks di media. Maraknya konten seks di majalah Hai menjadi bagian dari semangat liberalisasi dan industrialisasi.

Tulisan "Dari Redaksi Hai" edisi 15/10/1996 adalah awal Hai menggunakan istilah "seks", setelah sebelumnya memakai istilah "pergaulan sehat". Istilah "seks" akhirnya dipakai mengingat seks membawa banyak persoalan sehingga penting untuk didiskusikan secara terbuka. Maka tahun 1999, sesaat paska Orde Baru runtuh diikuti liberalisasi pers, Hai mengikuti semangat kebebasan tersebut, termasuk dalam mendiskusikan seks.

Dari sekian banyak tema yang dibahas dalam artikel-artikel seksualitas, tulisan ini fokus pada problem relasi laki-laki dan perempuan. Problem tersebut antara lain adalah pacaran, peran seksual, posisi laki-laki dalam masalah reproduksi perempuan, sikap laki-laki terhadap perempuan dan sebagainya. Lewat pembahasan persoalan tersebut, Hai membangun wacana tentang perbedaan gender, bagaimana menjadi laki-laki dan perempuan berkaitan dengan seksualitas. Hal tersebut akan dijabarkan dalam tulisan ini.

\section{Konstruksi Seksualitas dan Maskulinitas}

Seksualitas adalah relasi laki-laki atas perempuan yang tak terbatas pada hal-hal yang bersifat fisik, namun juga tindakan yang melibatkan kesenangan, sensasi, keintiman, rasa cinta, saling menjaga dan ketergantungan (Sprecher dan McKinney dalam Pearson, West dan Turner, 1995). Seksualitas mengatur peran seksual laki-laki dan perempuan. Misalnya laki-laki adalah pihak yang ekspresif menampilkan seksualitasnya, sementara perempuan seksualitasnya justru dikontrol dan dibatasi (Ibid, 1995).

Seksualitas menurut Kimmel (2005) merupakan konstruksi sosial yang menekankan bahwa seksualitas bukan semata-mata dorongan biologis, namun lebih ditentukan oleh proses sosialisasi yang spesifik pada waktu dan kultur tertentu. Hal itu menyebabkan seksualitas menjadi cair dan selalu berubah dari waktu ke waktu.

Seksualitas ditentukan oleh gender. Maskulinitas menentukan konstruksi seksualitas. Lewat pemahaman maskulinitas, seksualitas dikonstruksi. Melalui seksualitas, identitas gender seseorang dikonfirmasi. Gender mengkonfirmasi seksualitas dan seksualitas menginformasikan gender. Sebagai konstruksi, seksualitas dibentuk dan diproduksi di dalam wacana. Wacana seksualitas dibentuk lewat seperangkat aturan yang menentukan praktik wacana tersebut. Wacana seksualitas berelasi dengan sistem yang menempatkan apa yang dianggap patut dan tidak, benar dan salah, normal atau menyimpang yang didefinisikan lewat makna-makna yang beroperasi di dalamnya.

Wacana seksualitas beroperasi dalam sistem norma heteroseksual dan kultur patriarki yang mengklasifikasikan secara tegas laki-laki dan perempuan dalam relasi tertentu. Norma ini meletakkan laki-laki dan maskulinitas sebagai sentral kekuasaan serta mengatur hubungan seksual yang melibatkan jenis kelamin yang berbeda, yaitu laki-laki dan perempuan. Yang dianggap normal adalah laki-laki maskulin. Sementara homoseksual atau hubungan seksual yang 
melibatkan jenis kelamin yang sama, dianggap sebagai orientasi seksual yang tidak normal. Laki-laki homoseksual adalah laki-laki lemah yang tidak normal sehingga dieksklusikan dan diberi label tidak maskulin.

Beroperasinya rezim wacana atas seksualitas memunculkan hegemonic male sexuality (Plummer, 2005). Apa dan bagaimana laki-laki ditentukan oleh penis secara fisik dan simbolis. Penis bukan hanya ciri biologis laki-laki, namun menjadi simbol atas kekuatan dan dominasi laki-laki. Beberapa persoalan yang ditimbulkan oleh penis, seperti ukuran atau kemampuan dan ketahanan untuk ereksi menjadi standar seksualitas laki-laki.

Berdasarkan pandangan hegemonik, laki-laki aktif secara seksual. Sistem patriarki yang melegalkan praktik dominasi laki-laki atas perempuan mengakibatkan relasi yang timpang, termasuk peran seksual yang tidak setara. Laki-laki berperan sebagai pelaku dan perempuan adalah gatekeeper. Ketaksetaraan menghasilkan konstruksi laki-laki yang lebih seksual daripada perempuan. Laki-laki meningkatkan perilaku seksualnya untuk menunjukkan kelelakiannya, dan perempuan harus mengontrol perasaan seksualnya agar tak dianggap hina (Kimmel, 2005). Hal itu membenarkan laki-laki sebagai konsumen aktivitas seks, seperti pornografi, striptease, dan prostitusi (Plummer, 2005).

Benwell (2003) menjelaskan adanya hubungan yang intim dan sarat kuasa antara maskulinitas dan budaya populer. Majalah gaya hidup laki-laki sebagai budaya populer yang merepresentasikan maskulinitas dan menjadi situs sirkulasi, negosiasi, dan kontestasi makna-makna tentang maskulinitas, termasuk seksualitas.

\section{Metode Penelitian}

Penelitian ini memakai metode Analisis Wacana Kritis dari Norman Fairclough (2000) yang menyebut wacana meliputi penggunaan bahasa dalam bentuk tulisan, verbal, juga aktivitas semiotik yang meliputi citra visual dan komunikasi nonverbal. Ada tiga dimensi analisis: teks, sebagai rekaman peristiwa dan berfungsi mengkomunikasikan fakta tertentu; praktik diskursif, tentang proses produksi dan konsumsi teks; dan praktik sosiokultural yang melihat teks sebagai bagian dari praktik sosial dan budaya tertentu.

Sumber data penelitian ini adalah artikel seksualitas majalah Hai yang terbit tahun 1995-2004 sebagai periode transisi Orde Baru ke pasca Orde Baru. Pada periode ini pula terjadi perkembangan teknologi media dan komunikasi yang cepat serta berlangsungnya proses Islamisasi. Rentang waktu tersebut menggambarkan dinamika wacana seksualitas remaja laki-laki. Topik yang diteliti meliputi seks, identitas dan peran gender, erotisisme, kenikmatan, kemesraan, dan reproduksi. Artikel yang diteliti berjumlah 52 judul.

Dengan melihat bahasa sebagai wacana dan praktik sosial, maka analisis tidak hanya dilakukan terhadap teks, namun juga terhadap relasi antara teks, proses dan kondisi sosialnya, baik kondisi konteks situasional maupun kondisi struktur institusional dan sosial yang lebih luas (Fairclough, 2001). Dalam menganalisis bagaimana wacana relasi laki-laki dan perempuan dalam majalah Hai dilakukan tahap-tahap berikut: 
1. Tahap deskripsi menitikberatkan pada identifikasi properti formal teks. Bahasa tidak semata-mata mengkomunikasikan pesan, namun juga membawa makna tertentu.

2. Tahap interpretasi menitikberatkan relasi antara teks dan interaksi atau melihat teks sebagai produk dari proses produksi dan sumber dari proses interpretasi, peneliti melakukan analisis untuk melihat tujuan mengapa teks tertentu dipilih untuk ditampilkan. Untuk itu intertekstualitas dan interdiskursivitas menjadi perhatian.

3. Tahap eksplanasi menitikberatkan relasi teks dan konteks sosial, dilakukan analisis terhadap praktik sosial untuk melihat konteks sosiokultural yang melatarbelakangi produksi teks seksualitas dalam majalah Hai.

\section{Hasil Penemuan dan Diskusi}

Sebagai penganut paham heteronormatif yang menekankan perbedaan laki-laki dan perempuan, Hai mengkonstruksi identitas dan peran keduanya saat Hai membahas daya tarik dan peran secara seksual.

\section{Daya Tarik Seksual: Visual vs Afeksi}

Pembagian peran dan identitas secara seksual dimulai sejak kecil. Misalnya pada tulisan dalam Hai edisi 15/10/1996 berikut:

Pendidikan seks bahkan diberikan sejak kecil. Yakni ketika seorang anak diberitahu bahwa ia laki-laki atau perempuan, diberi celana atau rok, diberi mainan mobil-mobilan atau boneka. Dan ketika mulai besar, kamarnya dipisah. "Menyadarkan orang bahwa ia memiliki ciri seks yang berbeda. Kalau ini diteruskan; mengapa berbeda, apa perbedaan itu, apa jadinya, itulah pendidikan seks," kata Mas Ton.

Perbedaan laki-laki dan perempuan dijelaskan pada bagaimana keduanya menilai lawan jenis. Dalam artikel "Nonton Film Biru: Dorongan Atau Iseng?" (5/8/1999) dijelaskan bahwa laki-laki lebih menyukai film biru karena dalam menilai lawan jenisnya mereka lebih menekankan visualisasi, sementara perempuan menekankan afeksi.

Penekanan pada visualisasi menyebabkan tampilan fisik perempuan penting bagi laki-laki. "Seksi" menjadi sebutan perempuan berpenampilan fisik ideal. Perempuan seksi adalah perempuan bertubuh kurus, tinggi dan langsing atau padat, seperti tulisan berikut:

Daya tarik seseorang umumnya bisa diliat dari bagian tubuh. Gampangnya kalo seorang cewek punya bodi "kutilang" (kurus, tinggi, langsing) itu bisa disebut sexy. Apalagi padet (Sex Appeal: Nggak Harus Cakep dan Seksi, 17/9/1999).

Kalimat "Sex Appeal: Nggak Harus Cakep dan Seksi" bermakna sebagai berikut: "Sex Appeal perempuan adalah pada wajah "cakep" dan tubuh "seksi", namun jika kamu tidak memiliki wajah "cakep" dan tubuh "seksi" bukan berarti kamu tidak memikili sex appeal." Kata "nggak harus" bukan mengingkari wajah "cakep" dan tubuh "seksi". Penampilan wajah dan tubuh tetap penting tapi tidak mutlak. Penekanan pada visualisasi atau penampilan fisik menunjukkan posisi perempuan sebagai objek laki-laki.

Sementara itu, perempuan yang menekankan afeksi, bukan berarti mengabaikan penampilan laki-laki. Di sini terlihat ambivalensi Hai saat 
mewacanakan tubuh laki-laki. Di satu sisi, dengan menyebut perempuan lebih mementingkan afeksi daripada visual menunjukkan tubuh laki-laki bukan hal penting bagi perempuan. Namun, di sisi lain, Hai dalam beberapa tulisannya menuliskan perlunya laki-laki memperhatikan penampilan dan sex-appeal-nya. Hal ini menunjukkan laki-laki yang juga menjadi objek tatapan perempuan. Tertulis dalam artikel "8 Cara Meningkatkan Male Sex Appeal" (1/9/2003):

Man, kamu pengen jadi Don Juan alias lelaki pujaan sejuta wanita? Dimanapun berada selalu jadi inceran, kemanapun pergi selalu dikintilin cewek-cewek bonges? Cuma satu kuncinya, tingkatin male sex appeal kamu!

Tulisan tersebut memperlihatkan pentingnya laki-laki meningkatkan sex appeal-nya agar banyak perempuan tertarik. Don Juan adalah tokoh fiksi drama Spanyol yang identik dengan lelaki penakluk dan pujaan banyak perempuan. Ia adalah simbol maskulinitas dan male sexuality (Griffin, 1993) atau simbol male instinct (Murakami, 1998). Artikel di atas menjelaskan menjadi Don Juan adalah keinginan laki-laki, maka mereka perlu meningkatkan daya tarik seksualnya.

Daya tarik seksual yang dimaksud adalah kesempurnaan fisik dan personality. Karakteristik daya tarik seksual tersebut antara lain: postur tubuh atletis, tatapan dan lirikan mata yang bening dan berbinar, dan sikap berprinsip dan tanggung jawab. Dengan demikian tatapan perempuan atas tubuh laki-laki menjadi perhatian. Perempuan memiliki posisi penting bagi laki-laki dalam membentuk identitasnya. Rubrik "Kata Cewek" (1996) dan "Cowok Paling Takut" (1998) berisi pendapat perempuan tentang laki-laki. Kedua rubrik tersebut menunjukkan adanya kewajaran ketika perempuan membicarakan tubuh dan penampilan laki-laki, sehingga pendapat mereka bisa menjadi referensi laki-laki untuk membentuk identitas fisik, sikap dan perilakunya. Kedua rubrik adalah akomodasi terhadap kepentingan perempuan dan menjadi ruang refleksi bagi lakilaki.

Tubuh laki-laki menjadi tuntutan perempuan. Kondisi tersebut menunjukkan terjadinya pergeseran tatapan atau dalam Gill et. al (2005) diistilahkan sebagai "the shift of the gaze". Jika selama ini konstruksi budaya populer dan media massa, menjadikan perempuan sebagai objek tatapan laki-laki (male gaze), kini berbeda. Perempuan menjadi aktif, berkuasa dan bertindak sebagai penatap/pengamat laki-laki. Dalam relasi tersebut, posisi laki-laki seolaholah "diturunkan", bukan lagi subjek yang mengamati namun menjadi objek yang diamati. Sebagai objek, fokus perhatian dialihkan pada penampilan, yaitu tubuh dan wajah. Intinya, laki-laki memikirkan kini penampilan dirinya untuk menjadi objek tatapan perempuan. Namun, benarkah demikian?

Perhatikan kata "mangsa" dalam kalimat, "Sorot tajam dan lirikan nakal mata yang bening dan berbinar kabarnya selalu bisa bikin 'mangsa' bertekuk lutut!". "Mangsa" adalah sasaran atau objek (Kamus Besar Bahasa Indonesia, 2008). Kata "mangsa" mengacu pada perempuan. Memposisikan perempuan sebagai mangsa menunjukkan laki-laki adalah predator atau pemangsa. Analogi predator-mangsa yang paralel dengan laki-laki-perempuan menunjukkan superioritas laki-laki atas perempuan. Sorot dan lirikan mata laki-laki mampu menundukkan perempuan. Penilaian perempuan terhadap laki-laki memang penting, namun perempuan tetap menjadi objek bagi laki-laki. 
Frase "mahluk-mahluk manis" sebagai pengganti kata perempuan menegaskan hal tersebut. Kata "mahluk" merujuk ciptaan Tuhan, sehingga penggunaan frase "mahluk manis" untuk menggantikan perempuan berkonotasi positif, yaitu sebagai pujian. Namun istilah tersebut menunjukkan bagaimana perempuan sebagai sosok "manis" (cantik, indah) adalah objek tatapan laki-laki.

Superioritas laki-laki juga ditunjukkan pada bagaimana karakteristikkarakteristik daya tarik seksual merujuk pada hal-hal yang memposisikan lakilaki lebih kuat daripada perempuan. Tubuh atletis membuat perempuan merasa aman terlindungi; sorot mata tajam yang menundukkan; juga sikap tegas dan kemampuan melindungi perempuan.

Akhirnya, walaupun penampilan fisik menjadi aspek yang diperhitungkan, konstruksi perempuan lebih mengutamakan afeksi tetap lebih penting. Hal itu ditunjukkan saat Hai membahas cowok macho. Dalam artikel "Makin berbulu Makin Macho" (16/1/2001) disebutkan laki-laki macho tidak lagi ideal. Macho berarti sifat yang menonjolkan kekuatan fisik, kurang sensitif dan menjadi faktor gagalnya hubungan. Yang diinginkan perempuan adalah laki-laki seksi yang menghargai kesetaraan relasi dengan perempuan.

Dalam artikel tersebut, terdapat tulisan: "Stop Macho, Be Sexier" yang menjelaskan perbedaan istilah "macho" dan "seksi". Jika macho menonjolkan kekuatan fisik, maka seksi menekankan laki-laki yang bisa diajak berbincang dari hati ke hati, memiliki keterampilan berkomunikasi, punya rasa humor tinggi, menjadi pendengar, tidak menguasai pembicaraan, sensitif terhadap perempuan, melindungi, percaya diri, suka tersenyum, bersikap hangat dan bersahabat. Dengan demikian dapat disimpulkan adanya perbedaan kata "seksi" untuk lakilaki dan perempuan. Perempuan seksi dinilai berdasarkan penampilan fisik, sementara laki-laki seksi pada sikap atau afeksi.

\section{Berbagi Peran dalam Praktik Seksual: Inisiator vs Controller}

Connell (1987) menyebutkan laki-laki dan perempuan dibedakan sedemikian rupa lewat berbagai praktik sosial yang dinaturalkan sehingga menjadi ideologi seksual yang tidak terbantahkan. Semakin jelasnya kategorisasi maskulinitas dan femininitas membuat distingsi jenis kelamin yang berbeda terkesan semakin seksi dan erotis. Kondisi ini merupakan mekanisme yang membuat heteroseksualitas menjadi daya tarik. Adanya pernyataan seperti: "perbedaan antara laki-laki dan perempuan bersifat saling melengkapi dan mengisi kekurangan satu sama lain", semakin menaturalkan heteroseksualitas.

Identitas gender menjadi penting dalam distingsi tersebut. Butler (1990) menjelaskan ada regulatory practice yang menentukan batas dan esensi maskulinitas dan femininitas, termasuk relasi gender sebagai praktik interaksi individu dengan gender tertentu. Identitas gender ini menentukan identitas seksual, peran, hasrat dan praktik seksual. Hai membuat praktik seksual yang "normal" berdasarkan identitas gender.

Perbedaan laki-laki dan perempuan dinilai berdasarkan peran mereka dalam praktik seksual. Laki-laki menjadi pihak yang aktif memulai aktivitas seksual. Misalnya dalam tulisan artikel "Seksualitas Remaja: Mencari Tapal Batas" (15/10/1996), Hai mengutip beberapa pernyataan remaja tentang aktivitas 
berpacaran mereka.

"Cowok saya memang nggak sungkan-sungkan memeluk, merangkul, memegang tangan, atau mencium kening atau pipi di depan umum. Bukan untuk show off, tapi nunjukin rasa sayang aja." Mia (18) mengaku pacaran sudah dua tahun. Dua minggu jadi, sudah mulai cium bibir dan sebulan lalu mereka melakukan petting. "Yang mulai pacar saya dan terus terang saya terangsang....."

Tulisan di atas menunjukkan laki-laki adalah pelaku seksual aktif. Dalam artikel masturbasi dijelaskan bahwa masturbasi dilakukan laki-laki maupun perempuan. Namun, laki-laki kecenderungannya lebih tinggi. Artinya, laki-laki lebih mudah terangsang daripada perempuan. Masturbasi pada laki-laki dianggap sebagai hal wajar dan normal.

"Alat kelamin cowok kan letaknya di luar, sedangkan alat kelamin cewek itu di dalam. Itu dia sebabnya cowok jadi lebih mudah terangsang, dan lebih mudah menemukan titik-titik sensitif yang bikin dia ngerasa enak, meski mungkin nggak diniatin!" kata dokter Ferryal.

Tapi, kenapa juga sih kita-sebagai cowok-gampang banget kepikiran yang ngeres-ngeres dan seneng bermasturbasi? Liat pemandangan indah dikit langsung kelojotan. Bengong semenit, eh, langsung ngelonjor alias ngelamun jorok. Selanjutnya, tangan jadi gatel! $(22 / 3 / 2004)$

Kalimat yang dicetak tebal adalah penekanan dari peneliti untuk menunjukkan bahwa kalimat tersebut adalah hiperbola. "Kelojotan" adalah kejang-kejang. "Pemandangan indah" mengandung arti perempuan yang seksi. Melihat perempuan seksi lalu kejang-kejang merupakan kalimat yang melebihlebihkan. Dengan hiperbola, Hai menegaskan bahwa laki-laki begitu mudah terangsang hanya melihat perempuan yang dianggap seksi.

Konstruksi peran seksual laki-laki sebagai inisiator dilatarbelakangi pemahaman klasik kondisi laki-laki yang lebih mudah terangsang dibandingkan perempuan. Mudahnya laki-laki terangsang didukung fakta biologis, seperti dalam tulisan berikut ini:

Dalam berpacaran, secara faali pihak cowok bertabiat lebih gampang tancap gas dan telat injak rem (15/10/1996).

Dalam artikel "Kenapa Cowok Gampang "Nyetrum"” (24/1/1995), Hai melakukan perbandingan antara laki-laki dan perempuan untuk menunjukkan bahwa laki-laki lebih mudah terangsang. Misalnya dituliskan, "Sedikit aja ada "listrik" langsung "nyetrum"”. Mudah terangsangnya laki-laki dianalogikan dengan kalimat "tancap gas dan telat injak rem" yang berarti hasrat seksualnya mudah naik dan sukar diturunkan; dan "ada listrik langsung nyetrum", berarti mudah terangsang (nyetrum) jika ada rangsangan (listrik).

Kondisi tersebut adalah normal dengan merujuk penjelasan dokter. Ada tiga faktor yang mendukung hal tersebut. Pertama, soal biologis, dimana hipotalamus (bagian dalam otak yang mengatur besar kecilnya rangsangan yang masuk) laki-laki lebih besar dari perempuan. Hipotalamus yang lebih besar menyebabkan rangsangan yang diterima menjadi lebih kuat. Kedua, soal lingkungan, yang membentuk perbedaan antara laki-laki dan perempuan. Menurut pemahaman ini laki-laki yang berinisiatif, misalnya mencari nafkah, melamar perempuan, dan menjadi kepala rumah tangga. Ketiga, sistem nilai sosial budaya. Laki-laki yang dididik secara konservatif akan lebih tertutup dalam menerima rangsangan. Berdasarkan penjelasan tersebut, Hai membuat rasionalisasi tentang peran aktif seksual lewat penjelasan ilmiah, dalam hal ini diwakili oleh psikolog. 
Selain alasan medis, lebih mudahnya laki-laki terangsang juga didukung oleh norma-norma yang dipercaya di masyarakat. Norma-norma masyarakat yang memposisikan laki-laki sebagai pihak yang mudah terangsang adalah norma patriarkhis, atau yang disebut dalam artikel sebagai norma yang "cowok-oriented" (25/7/2000). Norma patriarkhis adalah norma yang memposisikan laki-laki sebagai pihak superior. Perbedaan nafsu laki-laki dan perempuan akibat persoalan budaya disinggung dalam artikel "Cowok Lebih Cepat Terangsang?" (24/3/2000). Biarpun laki-laki dan perempuan memiliki nafsu yang sama, laki-laki memiliki nafsu yang lebih reaktif daripada perempuan berdasarkan. Hal itu diperkuat oleh faktor biologis, psikologis dan sosial.

Laki-laki sebagai pelaku seksual aktif dibahas dalam artikel tentang fantasi. Dalam artikel "Ngintip Fantasi Seks Cewek" (31/5/2004), ada kekhawatiran di kalangan laki-laki bahwa perempuan juga mempunyai fantasi yang tidak kalah liar. Selanjutnya Dr. Ferryal menyatakan bahwa perempuan yang memiliki fantasi seks tidaklah sebanyak laki-laki. Artinya, laki-laki yang memiliki fantasi seks liar adalah wajar, sedangkan perempuan tidak. Asumsi tersebut didukung fakta budaya yang menganggap perempuan tidak pantas terlalu ekspresif berfantasi. Akibatnya perempuan cenderung lebih tertutup. Faktor pengalaman juga membuat fantasi laki-laki lebih variatif.

Laki-laki memiliki nafsu dan fantasi yang besar menjadi mitos, sehingga laki-laki tanpa nafsu dianggap bermasalah. Dalam artikel "Kamu Cowok Frigid?" (13/8/1999) disebutkan bahwa istilah "frigid" sebenarnya istilah yang biasa digunakan untuk menyebut perempuan yang mati rasa secara seksual, yang kemudian maknanya meluas kepada sikap dingin perempuan pada laki-laki. Jika itu terjadi pada laki-laki, maka kondisi tersebut menjadi tidak normal. Misalnya pada kalimat, "Tapi seorang cowok yang minus nafsu seks jelas punya masalah"; atau pada kalimat, "Dan lagi, rugi besar kalau melarut-larutkan masalah frigid ini. Bakal jadi cowok mubazir dong."

Perbedaan laki-laki dan perempuan ada pada nafsu. Perempuan dianggap tanpa nafsu, sementara laki-laki adalah pihak yang bernafsu. Dalam artikel tersebut dijelaskan bahwa hilangnya nafsu seks laki-laki diakibatkan persoalan psikologis. Istilah laki-laki "mubazir" menggambarkan laki-laki yang dianugerahi nafsu seks yang besar akan sia-sia jika ia merisaukan soal frigiditas yang bisa menghilangkan nafsu seksnya tersebut.

Kejantanan adalah hal penting bagi laki-laki yang diukur dari kesuburan. Judul artikel "Mandul: Kalo Setahun Nggak Ketemu Juga" (3/12/1999) adalah eufemisme tentang pertemuan penis dan vagina dalam hubungan seksual. Di sana tertulis, "Biarpun belum ingin punya anak, mandul bisa membuat seorang lakilaki merasa kurang". "Kurang" adalah ketaksempurnaan organ reproduksi yang merisaukan laki-laki, misalnya skrotum hanya satu, penis bengkok, air mani kental atau encer yang menghalangi kesuburan, atau tak lengkapnya jumlah testis. Tulisan berikut menyebutkan indikator kejantanan:

Bayangin ada cowok yang bijinya lebih dari dua. Dengan modal kelebihan kayak gitu, bisa dikira-kira seberapa besar keperkasaannya: Ceweknya banyak, anaknya juga berkeliaran di mana-mana, busyet (Satu Biji Nggak Berarti Mati, 24/9/1999) 
Kalimat "ceweknya banyak, anaknya berkeliaran di mana-mana" adalah hiperbola. Laki-laki yang memiliki banyak pasangan perempuan dan berhasil membuahi mereka sehingga memiliki banyak anak. Kata "berkeliaran di manamana" menggambarkan anak-anak yang berlarian ke sana ke mari. Kata "busyet" menunjukkan ekspresi keheranan $\mathrm{Hai}$ atas laki-laki yang memiliki pasangan dan anak yang banyak. Secara tersurat pernyataan tersebut menunjukkan keperkasaan diukur berdasarkan jumlah perempuan pasangannya dan anak yang dimilikinya. Keperkasaan identik dengan kejantanan. Simbol kejantanan dan dominasi laki-laki adalah penis dan organ pendukung lain, seperti buah zakar dan sperma. Penis disebut dengan istilah-istilah: "adek", "barang", "senjata", "sahabat sejati" (8/3/2004), “asesoris kejantanan", “onderdil”, "aset berharga" (19/1/2004). Hai menjadikan kejantanan adalah sesuatu yang penting. Judul "Satu Biji Nggak Berarti Mati" menunjukkan hal tersebut. "Satu biji" berarti ketidaksempurnaan testis laki-laki. Meski tidak sempurna bukan berarti "mati" atau tidak jantan. Kalimat tersebut berarti: meski tidak sempurna organ seksualnya, laki-laki tetap jantan atau perkasa atau superior.

Jika laki-laki adalah inisiator, maka perempuan memiliki peran pasif. Dalam aktivitas seks, perempuan menunggu inisiatif laki-laki. Hal itu digambarkan ilustrasi berikut:

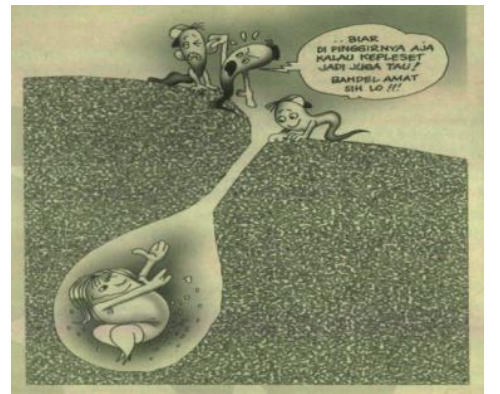

Gambar 1: Hai 20/8/1999

Lubang mengilustrasikan vagina, sementara tiga makhluk di atasnya mengacu pada sperma yang berunding agar tidak terpeleset ke dalam lubang. Di dalam lubang terdapat makhluk perempuan yang mengulurkan tangannya, menyambut tiga makhluk yang akan menghampirinya. Ilustrasi menyiratkan pasifnya perempuan dalam relasi seksual.

Berada di posisi subordinat yang pasif secara seksual membuat perempuan pelaku seksual dilekatkan label-label berkonotasi negatif. Pada tulisan di atas disebutkan sebagai perempuan yang menjual murah harga dirinya. Istilah "mangkal" yang menjelaskan tempat berjualan menjadi analogi perempuan yang bersedia berkencan dengan laki-laki untuk mendapatkan materi. Perempuan tersebut dianggap menjual harga dirinya. Perempuan pelaku seks bebas disebut dengan "pereks", atau "ayam" (22/8/1995).

Sementara itu, perempuan berperan sebagai controller dalam aktivitas seksual. Seperti dijelaskan di atas, laki-laki memiliki nafsu yang lebih besar daripada perempuan. Untuk itu sudah sewajarnya jika laki-laki menjadi inisiator dalam perilaku seksual. Agar tidak terjadi hal-hal yang tidak diinginkan sebagai konsekuensi atas perilaku tersebut, maka perempuan, yang "nafsunya lebih 
kecil", harus mampu mengontrol tindakan yang dilakukan oleh laki-laki. Perhatikan tulisan di artikel edisi 15/10/1996 berikut:

Dalam berpacaran, secara faali pihak cowok bertabiat lebih gampang tancap gas dan telat injak rem. Pihak cewek biasanya masih dalam kondisi sadar saat cowoknya sudah lebih dulu lupa daratan. Inilah saat orang pacaran berada di "kilometer 100" yang genting itu. Saat gas tak boleh ditancap lagi dan pedal rem sudah harus segera diinjak kalau tak ingin timbul kasus nasi sudah menjadi ketupat. Kalau saja pihak cewek terlanjur terbuai dan menjadi lupa mengingatkan untuk injak rem, maka "kecelakaan" yang tidak dicita-citakan pun terjadi. Yang terjadi, terjadilah! Sayang, waktu kejadiannya cuma beberapa detik saja setelah si cowok lupa daratan.

Istilah "kecelakaan" kembali digunakan untuk menjelaskan akibat seks premarital. Tabiat laki-laki dalam berpacaran dianalogikan dengan aktivitas berkendaraan. Laki-laki identik dengan "gampang tancap gas" (terangsang) dan "telat injak rem" (mengontrol nafsu). Legitimasi "secara faali" menjadi mitos laki-laki yang dianugerahi hasrat yang besar maka akan kesulitan untuk mengendalikannya. Sementara perempuan yang dianggap tidak bernafsu sebesar laki-laki dibebankan sebagai pengingat laki-laki untuk "menginjak pedal rem" (mengendalikan nafsu laki-laki). "Kecelakaan" (kehamilan tak diinginkan) adalah akibat kegagalan perempuan mengingatkan laki-laki "menginjak pedal rem".

Akibat tuntutan sebagai pengontrol, perempuan kerap disalahkan dalam perilaku seks bebas. Hai menunjukkan empati pada perempuan sebagai pihak yang menderita dalam terkena dampak perilaku seks bebas. Dalam kasus aborsi yang sering menjadi pilihan laki-laki, Hai memberikan ilustrasi tentang akibat yang diterima perempuan medis maupun psikis (dalam Panik Karena Ngehamilin: Bisa Sad End, Bisa Juga Happy End, 28/1/2002). Namun Hai masih membebankan perempuan sebagai kunci dalam seks bebas. Hai seolah-olah ingin menyampaikan karena perempuan adalah pihak yang paling menderita, maka perempuanlah yang seharusnya mencegah terjadinya seks bebas.

Melihat risikonya, cewek harus bisa tegas menyikapi dorongan seks yang menghampiri dia dan pasangannya. Kehamilan karena kebablasan, sedikit banyak menyimpan andil cewek $(25 / 7 / 2000)$.

Perilaku gonta-ganti pacar juga bukan barang baru. Malah buat sebagian cowok bisa dianggap sebagai petualangan. Herannya, banyak juga cewek yang terus lengket. Dilepas sayang, diterusin nyakitin. Mau apa coba? (3/9/1999)

Tanpa bermaksud jadi mojokin kaum cewek, liat aja betapa bebasnya mereka mereka itu berpakaian kala jalan-jalan di mal atau klabing. Mini bahan, tapi maksi "pengetahuan". Seakan ngebebasin kita juga buat memperluas plus menggali imajinasi yang terdalam $(15 / 3 / 2004)$

Kata-kata yang ditebalkan adalah contoh bagaimana laki-laki (kata "kita" merujuk pada laki-laki) menyudutkan perempuan. Kata "heran" atau "mau apa coba" adalah ungkapan laki-laki dalam memahami seksualitas perempuan yang ditunjukkan lewat pakaian ataupun kedekatannya dengan laki-laki. Hal tersebut menggambarkan perspektif laki-laki yang menganggap perempuan sebagai makhluk aseksual. Cara berpakaian dan bersikap adalah representasi perempuan yang menyalahi "kodrat" perempuan aseksual, yang tidak dianggap perempuan baik-baik. Ilustrasi berikut mendukung asumsi tersebut: 


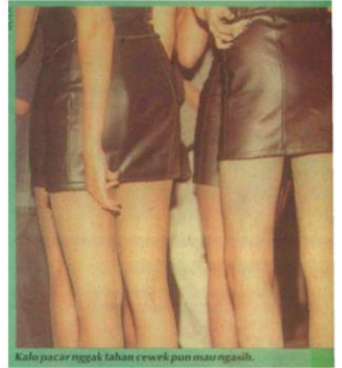

Gambar 2:

Hai edisi 6/10/2000

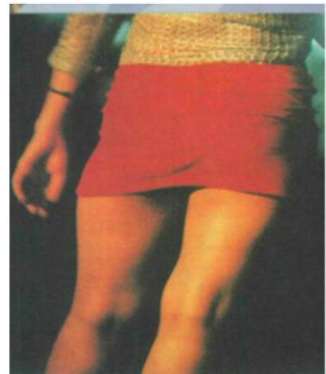

Gambar 3:

Hai edisi 25/7/2000

Gambar 2 mengilustrasikan perempuan memakai rok mini disertai caption "Kalo pacar nggak tahan, cewekpun mau ngasih", menunjukkan perempuan yang menampakkan pahanya menjadi pemicu hasrat laki-laki dengan membiarkan pacarnya melakukan seks bebas. Gambar 3, ilustrasi artikel "Turun Ke Jalan Demi Seks dan Drugs", menggambarkan pemakai rok mini adalah perempuan yang dekat dengan seks bebas. Rok mini kerap menjadi kontroversi, dan media memiliki andil atas hal tersebut (Lindawati, 2014)

Asumsi ini tentu saja relevan dengan penjelasan Hai bahwa laki-laki lebih menekankan aspek visualisasi dalam menilai lawan jenisnya disertai argumentasi medis bahwa laki-laki secara hormonal memang mudah terangsang. Penjelasan tersebut menjadi justifikasi bahwa laki-laki yang tergoda melakukan hubungan seksual adalah hal wajar karena secara biologis laki-laki adalah pelaku seksual aktif. Hubungan seksual terjadi saat perempuan gagal mengontrol laki-laki. Wacana tersebut menggeneralisasikan perempuan sebagai pihak yang bersalah. Bagi laki-laki baik alim atau preman (istilah Hai untuk menyebut laki-laki baikbaik dan laki-laki nakal) "dianugerahi" nafsu yang besar.

Perempuan sebagai penyebab tindakan seksual laki-laki didukung tulisan berikut:

Biasanya cowok cenderung jadi pelaku sex bebas, karena memang lebih mudah terangsang. "Jadi yang lebih ngeres itu biasanya laki-laki," ungkap Pak Irwanto. Makanya, kita harus hatihati, jack! Apalagi kalo pacar lo juga nggak punya iman yang kuat. Wah, bisa "kejadian", deh! $(3 / 3 / 2003)$

"Bergerilya" adalah sebenarnya akal-akalan orang aja untuk manfaatin suasana. Celakanya yang "digerilya" oke-oke aja (3/3/2003)

Istilah "bergerilya" dan "digerilya" memposisikan laki-laki sebagai pelaku "gerilya" dan perempuan adalah objek "gerilya". Kata "gerilya" berarti berperang secara sembunyi-sembunyi dan tiba-tiba (Kamus Besar Bahasa Indonesia, 2008:479). "Gerilya" (dengan tanda kutip) dalam artikel di atas berarti aktif dan agresif mencumbu yang identik dengan berperang. Ketika perempuan diposisikan sebagai pihak yang "digerilya" dan "oke-oke saja" (tidak keberatan) menunjukkan bahwa Hai menyalahkan perempuan sebagai penyebab perilaku seksual yang terjadi. Kata "celakanya" menunjukkan hal tersebut.

Dalam artikel "16 Cara Nahan Nafsu Di Bulan Puasa" (20/10/2003) disebutkan tips menahan nafsu yaitu meminta pacar berpakaian tertutup dan gombrong. Tujuannya agar tak ada kesempatan memandangi tubuhnya yang menimbulkan fantasi dan perilaku seksual lebih lanjut. Di situ dijelaskan bahwa 
tubuh perempuan mampu memprovokasi tindakan seksual laki-laki. Tips lainnya menghindari jalan-jalan ke tempat yang banyak ditemukan perempuan cantik dan berpakaian terbuka, misalnya dalam kalimat berikut:

"Nafsu liat cewek cakep bin sexy? Apalagi kalo cewek bajunya minimalis. Yang repot, baju ketutup tapi masih horny juga." (Gampang Horny!, 15/1/2004).

"Liat cewek cantik, langsung "melinting". Dikedipin pacar, eh, langsung "kepengen"' (Nafsu Gede=Hiperseks?, 23/8/2004)

Artikel "Seks Aman: Nggak Usah Takut Dibilang Chicken" (5/11/1999) menyebutkan tips menghindari godaan perempuan, "Jika terpaksa melihat perempuan "bohay" lewat, anggap saja sebagai rejeki". Ungkapan itu menganggap perempuan adalah objek hiburan.

Hai menyebutkan dalam norma masyarakat, perempuan harus menjaga sikap dan nafsunya. Misalnya di artikel tentang film biru yang menjelaskan mengapa perempuan tidak tertarik untuk menontonnya, salah satunya karena alasan norma yang mengharuskan perempuan menahan sikap dan perilaku seksualnya (30/7/1999).

Membahas norma, Hai memberlakukan standar yang berbeda bagi lakilaki dan perempuan. Perempuan menjadi penjaga moralitas, sementara ketika laki-laki melakukan hal yang dianggap tidak bermoral masih dimaklumi. Misalnya dalam artikel edisi 21/4/2000 yang membahas norma kepantasan berpacaran di dalam kamar. Tulisan di situ menunjukkan adanya standar ganda. Berpacaran di kamar laki-laki bisa diterima, tapi standar itu tidak berlaku jika lokasi pacaran ada di kamar perempuan. Laki-laki lebih permisif untuk mengajak pacar masuk ke kamarnya. Sementara jika perempuan yang mengajak pacar ke kamar dianggap menurunkan harga dirinya. Alasannya adalah tingkat privasi kamar perempuan lebih tinggi dibanding kamar laki-laki karena rahasia kamar perempuan menyangkut harga dirinya. Selain itu orang tua pihak perempuan lebih melindungi keperawanan perempuan. Secara tersirat hal itu menunjukkan bahwa keperjakaan laki-laki kurang dipentingkan daripada perempuan. Orang tua lebih protektif terhadap anak perempuan. Bukan hanya orang tua yang keberatan bila kamar perempuan dimasuki laki-laki. Seorang remaja laki-laki bernama Andro yang diminta opininya menganggap perempuan yang mengajak laki-laki masuk kamarnya adalah perempuan murahan. Ia sendiri tidak keberatan mengajak pacarnya berada di dalam kamarnya.

Di artikel tentang kondom, narasi tulisan menunjukkan perempuan sebagai penyimpan kondom. Anjuran ini berlaku bagi perempuan yang menjadikan seks sebagai profesi dan hiburan (6/10/2000). Hal ini menunjukkan peran perempuan sebagai pengontrol kehamilan atau penularan penyakit seksual dalam hubungan seksual.

Artikel "Kalau Ciuman Pertama Ditolak Cewek" (21/1/2000) menjelaskan penolakan Hai atas ketimpangan relasi laki-laki dan perempuan:

Padahal, soal mana yang lebih superior, cowok atau cewek sekarang udah nggak jamannya lagi dibahas. Cewek berhak menolak setiap perlakuan yang bikin dia merasa nggak nyaman, sekalipun itu dilakukan pacarnya

Meski begitu, perempuan tetap dianggap sebagai objek seksual dan penyebab rangsangan seksual. Misalnya tulisan-tulisan berikut (perhatikan katakata yang ditebalkan): 
Layaknya tayangan TV yang butuh sponsor, aktivitas seksual pada tubuh pun begitu. Semenjak mimpi basah pertama, jadi "gatel" kalo ngeliat cewek yang keren.

Obrolan santai yang ngeres, ngelamun erotis, apalagi kehadiran obyek yang "menarik" adalah macam rangsangan yang bisa menimbulkan sensasi seksual.

Kalo deg-degan ngeliat yang bikin ngiler lalu ereksi, berarti jantung tengah memompa darah ke pembuluh nadi dalam jaringan erektil di penis. (22/3/2004)

Biar kata mata lagi nggak kesandung pemandangan yang "indah-indah", otak juga nggak diniatin ngelonjor alias ngelamun jorok, eh, tau-tau basah! (19/4/2004)

Jangan berfantasi yang menjurus-menjurus kalo punya temen cewek yang cantik, kulitnya putih bersih, dan bodinya oke banget $(22 / 3 / 2004)$.

Elo suka melototin bodi cewek di depan mata? (Kalo nggak berarti bego atau nggak normal!). Bagian mana dari bodinya yang paling bikin lo nafsu? Atas, bawah, apa tengah? He he he kok, selera kita bisa beda ya?

Jack, bodi cewek tuh emang dahsyat ya? Biar kata tuh cewek pake baju yang tertutup rapat, bentuk bodinya yang penuh lekukan indah (beda sama bodi cowok yang lurus-lurus aja!) tetap bisa tembus pandang dan mencolok mata. He...he...he....

Tapi, biarpun dari ujung rambut sampe ujung kaki di bodi cewek bisa bikin kita tergoda, pasti ada satu bagian yang paling "sakti ". Bagian yang selalu ampuh bikin kita kelojotan dan ngehayal yang "nakal-nakal" setiap kali menatapnya! Auw....Tapi, udahlah, ngapain juga ngeributin selera kita yang beda beda terhadap bagian bodi cewek yang paling bikin nafsu. Sama atau beda, yang penting kan bisa menikmati! Ya toh...ya toh??? (23/12/2004)

Kasus pelecehan seringkali dilakukan cowok terhadap cewek. Misalnya nih, siapa yang nggak gatel merangkai kata-kata "menjurus," kalo ada cewek semok lewat pas kita nongkrong bareng temen $(28 / 5 / 1999)$

Walaupun memposisikan perempuan sebagai korban dan laki-laki sebagai pelaku, penyebutan istilah-istilah yang dicetak tebal pada kutipan-kutipan di atas menggambarkan perempuan sebagai sumber pelecehan yang terjadi.

Kalimat "layaknya tayangan TV yang butuh sponsor" adalah metafora, menggambarkan aktivitas seksual yang perlu pendukung atau sponsor, dan perempuanlah sponsor yang dimaksud. Penggunaan istilah-istilah seperti: "objek yang menarik", "yang bikin ngiler", "pemandangan yang "indah-indah"; atau deskripsi tubuh wanita, seperti: "temen cewek yang cantik, kulitnya putih bersih, dan bodinya oke banget", "body cewek: Atas, bawah, apa tengah?", "bodinya yang penuh lekukan indah", atau" bagian yang paling "sakti"”, "perempuan semok", bukan kata-kata yang memuji perempuan, namun justru ungkapan yang menggambarkan gagasan Hai bahwa tubuh perempuan adalah sumber hasrat dan rangsangan seksual laki-laki. Sebutan perempuan "semok" adalah bahasa gaul di kalangan remaja dan lazim digunakan oleh laki-laki yang sedang membicarakan perempuan yang seksi. Semok singkatan dari seksi dan montok.

Penjabaran di atas merupakan bentuk standar ganda atas peran seksual laki-laki dan perempuan yang dikonstruksi Hai. Sebagai kategori gender yang dikontraskan, laki-laki dan perempuan diperlakukan berbeda. Standar ganda yang terjadi adalah implikasi ketidaksetaraan gender dan ketidaksetaraan kekuasaan dalam masyarakat yang berbasis gender. Pemahaman ini didorong asumsi bahwa laki-laki lebih seksual dari perempuan. Laki-laki selalu berupaya meningkatkan simbol-simbol seksualnya untuk membuktikan kelaki-lakiannya, sementara perempuan membiarkan hasrat seksualnya tidak terpenuhi untuk menghindari kehinaan yang melekat padanya jika ia menunjukkan hasrat tersebut.

Kimmel (2006) berargumen kesenangan seksual adalah kemenangan lakilaki atas perempuan. Dominasi laki-laki menjadikan seksualitas sebagai kontrol 
terhadap perempuan. Hal ini menjadi logis bagi Hai sebagai majalah laki-laki. Pendidikan seks yang dilakukan Hai menjadi referensi bagi remaja laki-laki untuk melanggengkan kekuasaan dan dominasi laki-laki. Penekanan pada faktor medis dan psikologis yang didukung dokter dan psikolog menguatkan argumentasi Hai bahwa dominasi laki-laki secara seksual adalah hal yang natural. Hai tidak mengingkari faktor sosial kultural yang juga membentuk perbedaan peran seksual, namun karena penjelasannya lebih sedikit dan tidak didukung narasumber, menyebabkan faktor tersebut hanya menjadi pelengkap.

\section{Simpulan}

Berdasarkan analisis di atas peneliti menyimpulkan bahwa majalah $\mathrm{Hai}$ membangun wacana perbedaan gender yang ambivalen. Hal itu terlihat dalam analisis wacana kritis artikel seksualitas yang dipublikasikan tahun 1995-2004. Ambivalensi tersebut menjadi wujud akomodasi $\mathrm{Hai}$ atas berbagai wacana seksualitas, yaitu wacana konservatisme dan liberalisme seksual yang ada di Indonesia pada tahun 1990an dan 2000an.

Ambivalensi wacana perbedaan gender adalah strategi bertahan Hai dalam konteks ekonomi, sosial, dan politik. Bertahan secara ekonomi menjadikan konten seks sebagai komoditas potensial untuk dijual kepada pembaca dan pengiklan, juga sebagai akomodasi kepentingan generasi tua dan muda agar diterima dan menjadi pilihan semua kalangan. Bertahan secara sosial berarti eksistensi Hai tidak menimbulkan polemik di masyarakat. Wacana kebebasan seksual masih belum diterima pihak tertentu, seperti kelompok agama, terutama Islam yang pengaruhnya cukup kuat pada tahun 1990an dan 2000an. Namun, wacana ini digaungkan oleh kelompok lainnya, misalnya feminis dan pembela hak asasi manusia. Ambivalensi adalah upaya Hai untuk menjembatani kepentingankepentingan tersebut. Bertahan secara politik artinya tidak berkonflik dengan pemerintah. Kondisi ini menggambarkan kompromi Hai dan kepentingan pemerintah lewat penyampaian informasi seksualitas yang sejalan dengan kepentingan pemerintah.

Singkatnya, wacana seksualitas yang dibangun $\mathrm{Hai}$ adalah implikasi politik bermedia $H a i$ dalam merangkul berbagai kepentingan pihak yang mempengaruhi eksistensi majalah Hai dalam industri media cetak di Indonesia. Ambivalensi wacana merupakan jalan tengah atau negosiasi yang dilakukan $\mathrm{Hai}$ di antara berbagai kepentingan tersebut.

\section{Ucapan Terima Kasih}

Penulis mengucapkan terima kasih atas selesainya tulisan ini kepada beberapa pihak sebagai berikut:

1. Prof. Dr. PM Laksono dan Dr. Wening Udasmoro dari Fakultas Ilmu Budaya UGM selaku pembimbing riset dan disertasi penulis.

2. Irwan Iskandar dan Danie Satrio dari redaksi Majalah Hai

3. Tim Penilai dan Penguji dari Program Studi Kajian Budaya dan Media UGM. 


\section{Daftar Pustaka}

Baulch, Emma. (2002). Alternative Music and Mediation in Late New Order Indonesia, Inter-Asia Cultural Studies, 3(2).

Benwell, Bethan. (2003). "Introduction". Dalam Benwell, Bethan, Masculinity and The Men's Lifestyle Magazine, Oxford: Blackwell.

Butler, Judith. (1990). Gender Trouble: Feminism and Subversion of Identity, New York dan London: Routledge

Connell, RW. (1987). Gender and Power: Society, the Person, and Sexual Politics, California: Stanford University Press

Fairclough, Norman. (2000). Critical Analysis of Media Discourse". Dalam Marris P. \& Thornham, S., Media Studies: A Reader. New York: New York University Press

Fairclough, Norman. (2001). Language and Power. England: Pearson Education Limited

Gill, R., Henwood, K. \& Mclean, C. (2005). Body Projects and The Regulation of Normative Masculinity, Body and Society, 11(11)

Giroux, HA. (1998). "Teenage Sexuality, Body Politics and the Pedagogy of Display”. Dalam Epstein, J., Youth Culture: Identity in a Postmodern World, Oxford: Blackwell

Griffin, Gabriele. (1993). Heavenly Love?: Lesbian Images in Twentieth-century Women's Writing, Manchester: Manchester University Press

Kamus Besar Bahasa Indonesia. (2008). Jakarta: Pusat Bahasa Depdiknas

Kimmel, Michael S. 2005. Gender of Desire: Essays on Male Sexuality, Albany: State University of New York Press

Lindawati, Lisa. (2014). Rok Mini Di Persimpangan Jalan Antara Kebebasan Dan Eksploitasi, Jurnal Komunikasi, 6, (2). Terarsip di: https://journal.untar.ac.id/index.php/komunikasi/article/view/29

Murakami, Takayuki-Yokota. (1998). Don Juan East/West: On The Problematic Comparative Literature, New York: State University Of New York Press.

Nilan, Pam. (2006). "The Reflexive Youth Culture of Devout Muslim Youth in Indonesia”. Dalam Nilan, P. \& Feixa, C. Global Youth? Hybrid Identity, Plural Worlds. New York: Routledge

Pearson, JC., West, RL., \& Turner, LH. (1995). Gender and Communication, USA: McGraw Hill

Plummer, Ken. (2005). "Male Sexualities". Dalam Kimmel, MS, Hearn, Jeff \& Connel, RW. Handbook of Studies on Men and Masculinities, California: Sage Publications 